\title{
Transport and eruption of mantle xenoliths: A lagging problem
}

\author{
Kelly Russell ${ }^{1}$, Thomas Jones ${ }^{2}$, Graham Andrews $^{3}$, Ben Edwards ${ }^{4}$ \& Jennifer Pell ${ }^{5}$ \\ ${ }^{1}$ Department of Earth, Ocean \& Atmospheric Sciences, University of British Columbia, krussell@eos.ubc.ca \\ ${ }^{2}$ Department of Earth Sciences, Durham University,UK, tomjj7@gmail.com \\ ${ }^{3}$ Department of Geology \& Geography, West Virginia University, USA, gda0005@mail.wvu.edu \\ ${ }^{4}$ Department of Earth Sciences, Dickinson College,USA, edwardsb@dickinson.edu \\ ${ }^{5}$ Peregrine Diamonds Ltd, Vancouver, Canada, jennifer@pdiam.com
}

\section{Introduction}

One of the main characteristics of kimberlite magmas is the nature and abundance of xenolithic cargo they sample, entrain, transport, and erupt. The population of xenoliths hosted by kimberlite commonly represents random sampling from anywhere within the entire (i.e. $\sim 150-200 \mathrm{~km}$ ) cratonic mantle and crustal lithosphere. Much of our knowledge of the nature and origins of the subcratonic mantle lithosphere derives directly from our petrological, geochemical and geophysical studies of the xenoliths recovered from kimberlite. Furthermore, the diamond content and economic potential of kimberlite bodies relies exclusively on the successful sampling and transport of mantle cargo originating within the diamond window. Magma ascent velocities are rapid; one line of evidence for this is that xenoliths may be thermally equilibrated with the magma but are not chemically equilibrated and record mantle conditions (Mitchell, 1980). The entrainment of dense mantle cargo also constrains magma rise rates (e.g., Sparks et al. 1977; Mercier, 1979; Spera, 1984; Sparks et al. 2006).

Current models for xenolith sampling and transport are commonly based on the Stokes settling rates determined by the size and density of the mantle cargo relative to the properties of the kimberlite melt. Despite the flaws in these relatively simple calculations, they accentuate the fact that the dense mantle cargo is continually settling through the less dense, low viscosity melt as the kimberlite magma ascends. This implies that xenoliths are potentially being decoupled from the magma that actually sampled them and suggests that a substantial lag time exists between eruption of the magma that sampled the xenoliths and eruption of the lagging xenolithic cargo. Here, we explore the implications of these concepts for the distribution of xenoliths within kimberlite deposits and, in particular, for the distribution of mantle xenoliths derived from within the diamond window.
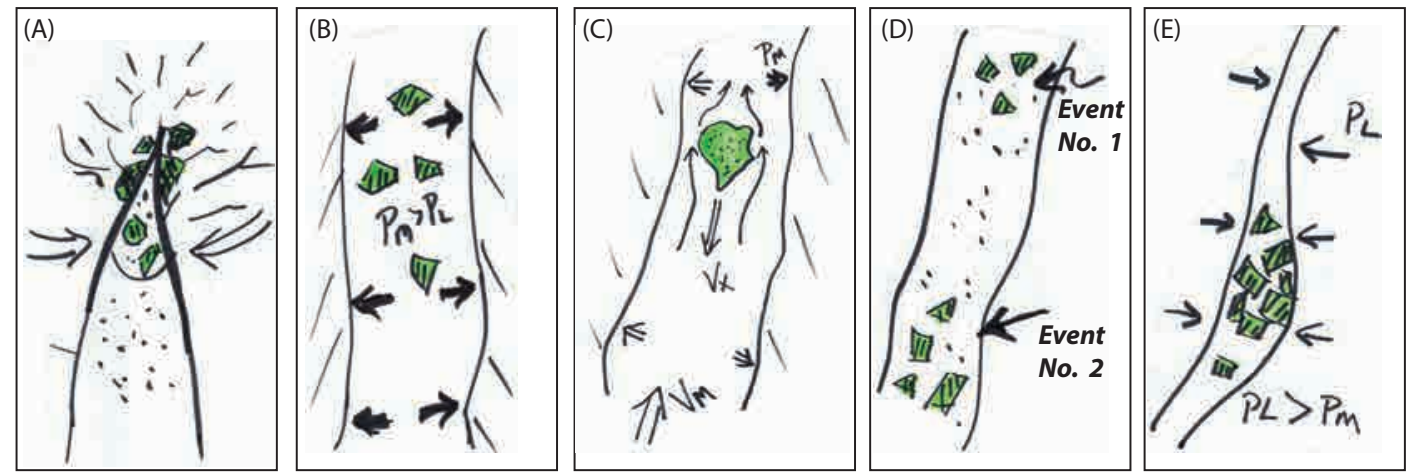

Figure 1. Schematic representation of events attending sampling and transport of mantle xenoliths. (A) Fluidfilled crack tip at head of kimberlite dyke causes brittle damage of mantle providing fragmented material for entrainment. (B) During peak flow, magma pressure $\left(\mathrm{P}_{\mathrm{M}}\right)$ in the kimberlite dyke exceeds lithostatic pressure $\left(\mathrm{P}_{\mathrm{L}}\right)$ sustaining magma ascent and xenolith entrainment. (C) Kimberlite ascent velocities $\left(V_{M}\right)$ need to be high enough to compensate for settling of denser mantle cargo $\left(\mathrm{V}_{\mathrm{X}}\right)$. (D) Xenolith clusters maintain their initial positions relative to other clusters under laminar flow conditions. (E) Field observations of xenolith-bearing dykes are compromised because of dyke relaxation.

\section{Factoids on Xenolith Transport}

Mantle xenoliths are extracted by brittle deformation of the surrounding lithosphere by buoyant kimberlite magmas where the stresses imposed by the crack tip at the head the buoyant magma exceed the tensile strength of the wall rocks at depth (e.g., Spera, 1984; Lensky et al. 2006; Wilson and Head, 2007). Dyke propagation through the damaged mantle lithosphere samples and entrains xenoliths (Fig. 
1A). Xenoliths continue to sink in the magma as it ascends (Fig. 1C) and require ascent velocities in excess of the settling velocities to reach the surface (Sparks et al. 1977; Spera, 1984; Sparks et al. 2006).

The majority of xenoliths derive from sequential dyke propagation events wherein the damage zones surrounding the dyke's crack tip are sampled (Fig. 1D; Lensky et al. 2006; Brett et al. 2012). Theoretically, after each sampling event, xenoliths should remain clustered together and should preserve their position within the rising magma relative to other clusters of xenoliths (Fig. 1D). However, mixing by turbulent flow could disseminate clusters. Sorting of mantle xenoliths by size (densities are essentially equivalent) is a relatively inefficient process given the average ascent rates of kimberlite. When magma pressure decreases during the waning of ascent, widths of dykes decrease as the system relaxes thereby compromising field observations (i.e. Kavanagh and Sparks, 2011). However, in some instances, dykes closing during the waning stages of an eruption trap clusters of xenoliths and preserve evidence for the minimum dyke thicknesses during transport (Fig. 1E).

\section{Basic Stokes Velocities}

The terminal settling velocities $\left(V_{X}\right)$ of dense solids (xenoliths) in viscous melts are predicted with Stokes law for spherical particles under laminar flow as a function of melt viscosity $(\eta)$, particle radius $(r)$ and the density contrast between melt and xenolith $(\Delta \rho)$ (e.g., Spera, 1984):

$$
V_{X} \cong \frac{2 \mathrm{~g} \Delta \rho r^{2}}{9 \eta}
$$

One implication of mantle xenoliths being erupted is that the host magma must ascend at rates $\left(V_{m}\right)$ faster than the xenoliths are sinking (i.e. $V_{X}$; Eq. 1; Sparks et al. 1977; Spera 1984). During ascent, the xenoliths are sinking through the rising magma producing a lag time $(\Delta \mathrm{t})$ given by:

$$
\Delta t=\frac{D_{x}\left(V_{m}-V_{x}\right)}{V_{m} V_{x}}
$$

where $D_{x}$ is the source depth of the xenolith. For example, a differential rise velocity of $1 \mathrm{~m} \mathrm{~s}^{-1}$ between the kimberlite melt $\left(+4 \mathrm{~m} \mathrm{~s}^{-1}\right)$ and a mantle xenolith $\left(-3 \mathrm{~m} \mathrm{~s}^{-1}\right)$ sampled at a depth of $150 \mathrm{~km}$ implies a time lag of $\sim 3.5$ hours (Fig. 2).

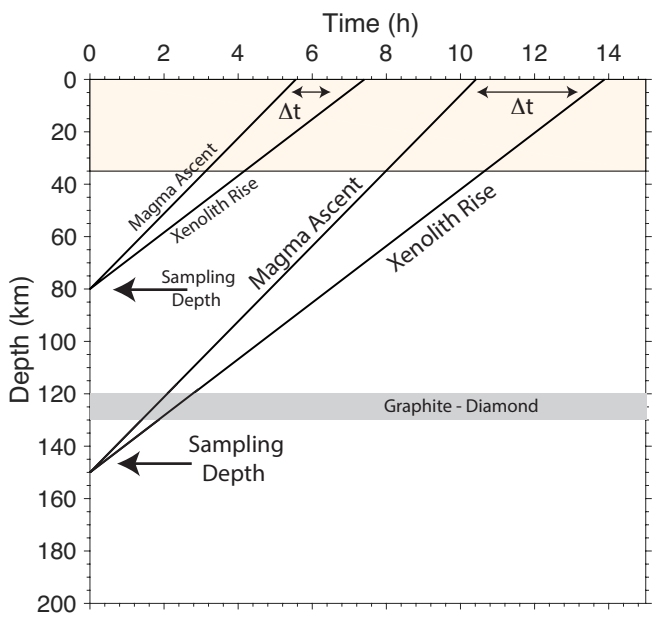

Figure 2. Model lag times for mantle xenoliths having a differential velocity of $1 \mathrm{~m} \mathrm{~s}^{-1}$ and depending on source depth.

In general, the deepest sourced mantle xenoliths will have the greatest lag times, as well as the greatest transport times. Shallow sampled mantle xenoliths will tend to be more strongly coupled the magma and have shorter lag times. Crustal xenoliths are likely to be more or less fully coupled to the kimberlite magma and be erupted continuously throughout the eruption and by the same magma that sampled them. In contrast, deeply sourced xenoliths from within the diamond window are likely to erupt hours after the magma that actually caused the original sampling. These xenoliths are at risk of being left behind if eruption durations are short or magma volumes

are small. Xenoliths sampled at depths of $D_{x}$ will commonly be inherited and erupted by deeper/later magma $\left(D_{m}\right)$ as described by:

$$
D_{m}=\frac{D_{x} V_{m}}{V_{x}}
$$

such that the pairing between kimberlite magma and erupted xenoliths is dependent on the sampling depth and the relative rise velocities of magma and xenolith.

\section{Other Considerations}

The concepts developed above derive from the assumption that Stokes law for settling of spherical particles is an adequate representation of the behavior of mantle xenoliths entrained by 
kimberlite magma. Whilst silicate melts are Newtonian under normal shear strain rates, magmas can become non-Newtonian (Bingham) if crystal contents are high and develop a yield strength $\left(\sigma_{0}\right.$; Sparks et al. 1977; Spera, 1984). Yield strengths will reduce the critical rise velocity required for the magma to successfully carry the mantle cargo. Indeed, small xenoliths can be fully coupled to the magma where the shear stress of the settling particle $\left(\sigma_{\mathrm{x}}\right)$ is $<\sigma_{\mathrm{o}}$. However, the concept of a lag time between the magma and xenolith is preserved for all xenoliths having $\sigma_{\mathrm{x}}>\sigma_{\mathrm{o}}$.

Crystals in silicate magmas can enhance nucleation of bubbles of $\mathrm{H}_{2} \mathrm{O} / \mathrm{CO}_{2}$ and xenolith entrainment represents another means of enhancing bubble nucleation. Experiments with carbonated liquids and rough-surfaced solids (e.g. 'Menthos ${ }^{\mathrm{TM}}{ }_{1}$ candies) demonstrate the importance of surfaces for causing rapid, heterogeneous nucleation of bubbles. Xenolith roughened by attrition processes (Campbell et al. 2012; Jones et al., 2014) provide ideal surfaces for inducing vesiculation (i.e. Menthos effect; Edwards and Russell, 2009) thereby facilitating xenolith transport in 3 ways. The addition of bubbles will also introduce a non-Newtonian rheology and lead to shear-thinning characteristics and possibly viscoelastic behavior. Bubbles can lower the density of xenoliths by adhering to and coating xenolith surfaces (Edwards and Russell, 2009), as well as, hinder settling. Thirdly, a decrease in volatile content of the melt will increase melt viscosity. The 'Menthos' effect could also be driven by deepseated assimilation-driven vesiculation of $\mathrm{CO}_{2}$ (Russell et al. 2012).

\section{Conclusions}

Differential velocities between a rising kimberlite magma and the mantle xenoliths it samples leads to substantial lag times between the eruption of magma and xenolith cargo. These lag times have important implications for the total volume of magma rising, the duration of kimberlite eruptions, the length (depth) of dyke that is open at depth during the eruption, and, ultimately, the distribution of diamonds within kimberlite eruption products.

\section{References}

Brett, RC, Russell, JK, Andrews, GDM \& Jones, TJ (2015) The ascent of kimberlite: Insights from olivine. Earth \& Planet Sci Lett 424, 119-131.

Campbell, M Russell, JK \& Porritt LA (2013) Thermomechanical milling of accessory lithics in volcanic conduits. Earth \& Planet Sci Lett 377-378, 276-286.

Edwards, BR \& Russell, JK (2009) Xenoliths as magmatic 'menthos'. GAC-MAC \& AGU Joint Annual Spring Meeting with Abstracts, Toronto, Canada.

Jones TJ Russell JK Porritt LA \& Brown RJ (2014) The morphology and surface features of olivine in kimberlite lava: implications for ascent and emplacement mechanisms, Solid Earth 5, 2283-2312.

Kavanagh, JL \& Sparks, RSJ (2011) Insights of dyke emplacement mechanics from detailed 3D dyke thickness datasets. J Geol Soc 168, 965-978.

Lensky, NG, Niebo, RW, Holloway, JR, Lyakhovsky, V \& Navon, O (2006) Bubble nucleation as a trigger for xenolith entrapment in mantle melts. Earth \& Planet Sci Lett 245, 278-288.

Mercier, JC 1979. Peridotite xenoliths and the dynamics of kimberlite intrusion. The Mantle Sample: Inclusion in Kimberlites and Other Volcanics, 197-212.

Mitchell, RH, Carswell, DA \& Clarke, DB (1980) Geological implications and validity of calculated equilibration conditions for ultramafic xenoliths from the pipe 200 kimberlite, northern Lesotho. Contrib Mineral Petrol 72, 205-217.

Russell, JK, Porritt, L, Lavallee, Y \& Dingwell, D (2012) Kimberlite ascent by assimilation-fuelled buoyancy. Nature 481, 352-356.

Sparks, RSJ, Baker, L, Brown, RJ, Field, M, Schumacher, J, Stripp, G \& Walters, A (2006) Dynamical constraints on kimberlite volcanism. J Volc Geotherm Res 155, 18.

Sparks, RSJ, Pinkerton, H \& Macdonald, R (1977) The transport of xenoliths in magmas. Earth \& Planet Sci Lett 35, 234-238.

Spera, FK (1984) Carbon dioxide in petrogenesis III: role of volatiles in the ascent of alkaline magma with special reference to xenolith-bearing mafic lavas. Contrib Mineral Petrol 88, 217-232.

Wilson, L \& Head, JW (2007) Integrated model of kimberlite ascent and eruption. Nature 447, 53-57. 